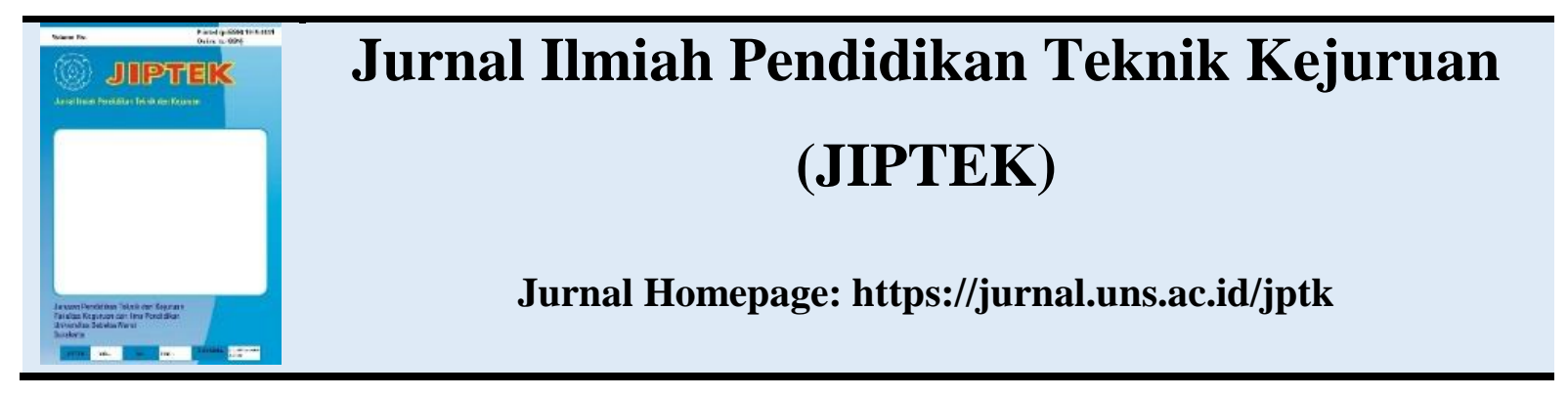

\title{
PEMANFAATAN APLIKASI ANDROID DAN VIDEO PEMBELAJARAN UNTUK MENINGKATKAN HASIL BELAJAR PESERTA DIDIK DALAM MATERI JARINGAN KOMPUTER
}

\author{
Arif Sulistyo Atmoko \\ Program Profesi Guru, TKI, Universitas Sebelas Maret Surakarta \\ Jalan Ahmad Yani 200 Surakarta \\ Email: arifsa82@gmail.com
}

\begin{abstract}
ABSTRAK
Tujuan dari kegiatan ini adalah untuk meningkatkan hasil belajar peserta didik dalam mempelajari materi jaringan komputer dengan menggunakan media ajar berupa aplikasi android pengganti lms dan video pembelajaran. Subyek kegiatan ini adalah peserta didik kelas XII IPA 4 SMA N 1 PECANGAAN. Metode yang digunakan dalam kegiatan ini adalah penelitian tindakan kelas tentang hasil belajar peserta didik. Dalam melaksanakan kegiatan ini, peserta didik diminta untuk mengikuti pre-test dan post-test. Yang dimana hasil dari kegiatan penelitian ini terjadi peningkatan hasil belajar peserta didik dikarenakan meningkatnya pemahaman terhadap materi jaringan komputer yang diberikan dalam bentuk media ajar berupa aplikasi android dan video pembelajaran
\end{abstract}

Kata kunci: Aplikasi Android

\begin{abstract}
The purpose of this activity is to improve the learning outcomes of students in studying computer network material using teaching media in the form of an Android application to replace MMS and learning videos. The subjects of this activity were students of class XII IPA 4 SMA N 1 PECANGAAN. The method used in this activity is classroom action research on student learning outcomes. In carrying out this activity, students are asked to take the pre-test and post-test. Which is where the results of this research activity increase student learning outcomes due to increased understanding of computer network material provided in the form of teaching media in the form of android applications and learning videos
\end{abstract}

Keywords: aplication android 


\section{PENDAHULUAN}

SMA N 1 Pecangaan adalah salah satu dari banyak sekolah yang melaksanakan kegiatan School From Home. Dimana kegiatan ini menggantikan kegiatan Belajar Mengajar yang dilakukan didalam kelas, yang didalamnya terdapat kegiatan guru bertemu siswa, kegiatan diskusi, presentasi dan lain sebagainya menjadi kegiatan Pembelajaran Jarak Jauh (Daring) secara keseluruhan.

Dimasa Pandemi Guru dan Peserta didik selama kegiatan pembelajaran salah satunya menggunakan media ajar berupa LMS yang disediakan oleh sekolahan yang digunakan untuk menunjang kegiatan pembelajaran asynchronous. Dan didalam kegiatan pembelajaran, sering kali menerapkan konsep pembelajaran berbasis teks sehingga pembelajaran berbasis teks cenderung dirasa membosankan karena yang dihadapi teks tersebut secara terus menerus.

Sedangkan didalam penggunaan LMS sekolahan yang berbasis teks, juga memunjulkan permasalah karena peserta didik merasa kesulitan untuk tidak bisa mengakses materi pembelajaran secara mudah dan cepat sehingga mengakibatkan penurunan hasil belajar peserta didik.

Berdasarkan pengamatan dan observasi memang diperlukan media pembelajaran yang mampu meningkatkan hasil belajar peserta didik. Menurut Sharon E. Smaldino dan James D. Russel (2005:9) media pembelajaran menjadi penghubung antar guru dan murid, berkat media siswa tidak lagi dibatasi batas-batas ruang kelas. Siswa dapt belajar diberbagai tempat melalui internet maupun ponsel mereka.

Melalui Penelitian tindakan kelas

(PTK) yang memanfaatkan Aplikasi Android sebagai pengganti LMS dan Video Pembelajaran untuk menggantikan bahan ajar berbasis teks. Yang dimana kegiatan Penelitian ini memiliki tujuan untuk meningkatkan hasil belajar peserta didik khususnya serta meningkatkan kemampuan peserta didik didalam penggunaan teknologi di abad 21. Serta dapat membantu mempermudah peserta didik didalam memahami materi pembelajaran tentang jaringan komputer.

Selain itu keunggunalan mobile learning/aplikasi android dapat digunakan untuk mengatasi keterbatasan, selain itu mudah dibawa, dapat terhubung kedalam jaringan kapan saja dan dimana saja, lebih fleksibel dalam mengakses sumber belajar, kedekatan komunikasi, siswa dapat terlibat dan aktif (Woodill, 2012:4)

\section{METODE PENELITIAN}

Pada penelitian ini, peneliti berusaha mendeskripsikan bentuk pembelajaran untuk meningkatkan pemahaman siswa dengan menerapkan pembelajaran berbasis android pada materi jaringan komputer.

Jenis penelitian ini menggunakan penelitian tindakan kelas (classroom Action Research) karena peneliti bertindak secara langsung dalam penelitian, mulai dari awal sampai akhir tindakan. Menurut suharsimi dalam (Dila 
Canrawati, 2013:32) bahwa PTK merupakan paparan gabungan deifinis dari tiga kata "penelitian, tindakan dan kelas". Penelitian adalah kegiatan mencermati suatu obyek, menggunakan aturan metodologi tertentu untuk memperoled data atau informasi yang bermanfaat bagi peneliti dalam rangka peningkatan kualitas hasil belajar peserta didik.

Sedangkan menurut Bogdan dan Biklen dalam (Bogdan \& Biklen, 1992:233) merumuskan penelitian tindakan sebagai suatu aktivitas pengumpulan informasi secara sistematis yang dirancang untuk membawa atau menghasilkan perubahan. Dan menurut kemmis (kemmis, 1983) p.162 Action research is a form of self-reflective enquiry undertaken by participants in social (including educational) situations in order to improve the rationality and justice of (a) their own social or educational practices, (b) their understanding of these practices, and (c) the situation in which the practices are carried out. It is most rationally empowering when undertaken by individuals, and sometimes in cooperation with 'outsiders'. In education, action research has been employed in school-based curriculum development, school improvement programs, and system planning and policy development

Sesuai dengan tujuannya yaitu menghasilkan suatu perbaikan atau perubahan khususnya pada proses pembelajar, proses tersebut digambarkan secara skematis oleh kemmis di gambar dibawah ini

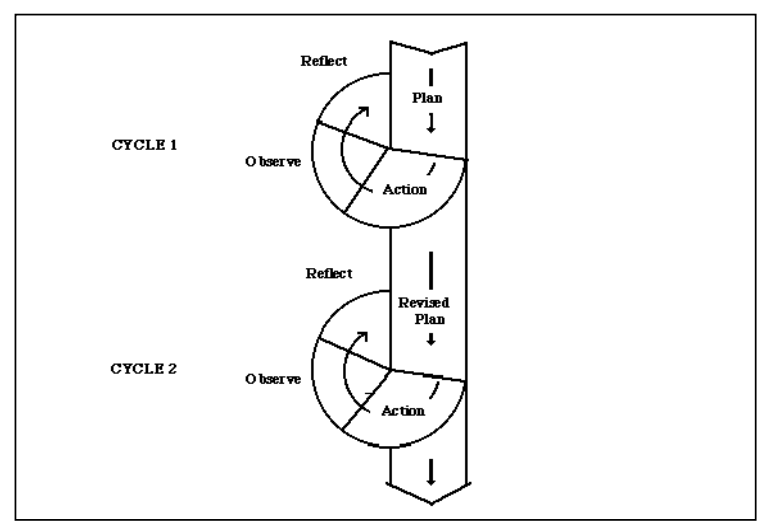

Gambar 1. Siklus PTK

Gambar diatas menunjuukan bahwa ptk terdiri empat tahapan yaitu perencaan, pelaksanaan, pengamatan, dan refleksi yang dimana kegiatan Penelitian tindakan kelas dengan subyek kelas XII IPA 4 SMA N 1 PECANGAAN pada tahun pelajaran 2020/2021

Pada tahap Perencanaan peneliti menyusun instrumen penelitian yang diperlukan selama proses perbaikan pembelajaran, seperti RPP, bahan ajar, evaluasi pre-test dan post-test, membuat video pembelajaran, menyusun LKPD dan menyiapkan aplikasi android dengan memanfaatkan google sites yang telah di rubah dalam bentuk aplikasi android

Pada tahap pelaksanaan penelitian tindakan kelas, peniliti melakukan kegiatan Pembelajaran Jarak Jauh dengan menggunakan LMS sekolahan yang didalamnya sudah diberikan materi dalam bentuk modul/ebook, video pembelajaran dan panduan penggunaan LKPD 1 dan juga memasukan materi tersebut kedalam google sites yang dimana akan dapat di akses peserta didik melalui aplikasi android secara langsung dan cepat.

Untuk membantu pemahamaan peserta didik penilit memanfaatkan google meet untuk melakukan kegiatan syncronous, dan pemanfaatan telegram grup untuk kegiatan 
asynchronous yang dimana kegiatan pembelajaran baik LKPD, evaluasi dan absensi juga terhubung didalam aplikasi andorid selain itu kegiatan evaluasi pre-test dan post-test serta LKPD yang terdapat didalam aplikasi andorid akan digunakan untuk menganalisa perkembangan peserta didik, dan mengukur hasil belajar siswa setelah dikenai tindakan

Untuk tahapan kegiatan pengamatan peneliti mengamati secara langsung proses kegiatan di LKPD dan proses evaluasi, yang dimana hasil evaluasi baik pre-test dan post-test akan dijadikan analisis perkembangan kemampuan peserta didik tentang materi jaringan komputer. Sedangkan dalam Tahapan Refleksi Dilakukan berdasarkan hasil didalam LKPD 1 dan evaluasi yang telah diperoleh pada tahapan observasi.

\section{HASIL PENELITIAN DAN PEMBAHASAN}

Penggunaan aplikasi android dengan dukungan google sites sebagai pengganti LMS sekolahan serta materi pembelajaran berupa video pembelajaran sebagai pengganti ebook dapat meningkatkan pengetahuan tentang materi jaringan komputer. Berdasarkan hasil pre-test yang dilakukan sebelum pelaksanaan kegiatan menunjukan bahwa peserta didik yang terlibat sebegai peserta dalam kegiatan tersebut dengan jumlah 36 siswa, 16 peserta didik tuntas atau sebesar $44 \%$ dan masih terdapat peserta didik sebanyak 7 siswa atau sebesar $19 \%$ tidak tuntas dan 13 peserta didik atau sebesar $36 \%$ persen tidak mengikuti kegiatan pre-test, hal ini dikarenakan peserta didik sedikit kesulitan didalam memahami materi terbaru tentang jaringan komputer. Sehingga banyak sekali peserta didik yang tidak ingin mencoba mengerjakan pre-test.

Setelah dilaksanakan pembelajaran dengan menggunakan bantuan media ajar berupa aplikasi android yang didalam nya terdapat materi berupa video pembelajaran tentang jaringan komputer dapat menunjukkan peningkatan sebesar $50 \%$ dari 16 peserta didik tuntas ketika didalam pre-test menjadi 34 peserta didik tuntas didalam post test. Sedangkan ketidak tuntasan berkurang dari 19\% menjadi $6 \%$ yaitu dari 7 peserta didik didalam pre-test menjadi 2 ketika didalam post-test. Secara grafik dapat dilihat dalam grafik 1.1 berikut :

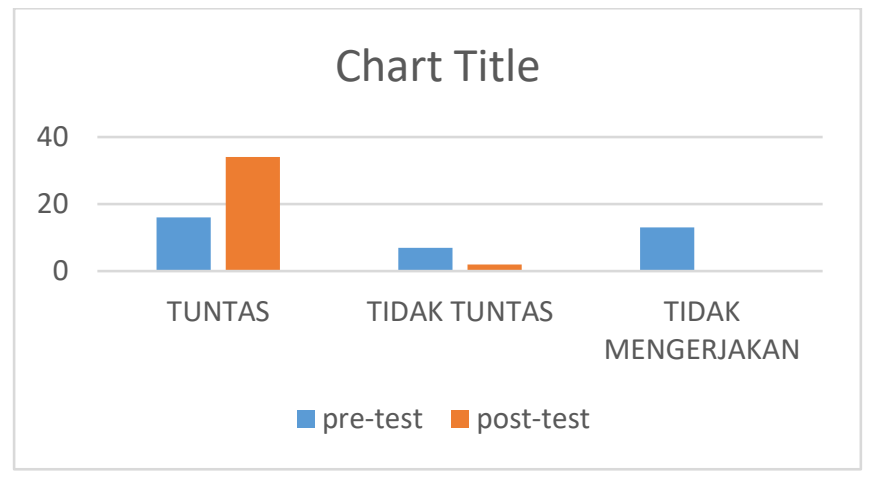

Gambar 2. Grafik Hasil perbandingan pre-test dan post test

Berdasarkan hasil pre-test dan post-test yang telah dilakukan ditemukan fakta bahwa media pembelajaran yang berupa aplikasi android sebagai mobile learning untuk mengantikan lms sekolahan serta video pembelajaran yang menggantikan ebook memberikan dampak yang signifikan terhadap peningkatan hasil belajar peserta didik. Sebagaimana dijelaskan oleh Sharon E. Smaldino dan James D. Russel (2005:9) bahwa Media pembelajaran menjadi penghubung antar guru dan murid, berkat media 
siswa tidak lagi dibatasi batas-batas ruang kelas. Siswa dapt belajar diberbagai tempat melalui internet maupun ponsel mereka. Ini sesuai dengan apa yang disampaikan.

\section{SIMPULAN DAN SARAN}

\section{Simpulan}

Berdasarkan dari hasil kegiatan penelitian diatas dapat disimpulkan bahwa dengan menggunakan media pembelajaran yang berupa aplikasi android yang dapat mempermudah mengakses materi pembelajaran serta video pembelajaran sebagai pengganti materi yang berupa ebook dapat meningkatkan hasil pengetahuan peserta didik tentang materi jaringan komputer. Simpulan ini didapatkan dari hasil analisis pretest dan post-test yang dilakukan ketika pelasanaan kegiatan

\section{Saran}

Kegiatan ini dapat diterapkan di sekolah lain untuk meningkatkan hasil belajar peserta didik, harapannya juga meningkatkan kemampuan peserta didik didalam pemanfaatan teknologi lebih baik lagi.

\section{DAFTAR PUSTAKA}

Bogdan, R. C., \& Biklen, S. K. (1992). Qualitative reserach for education. An introduction to theory and methods. Boston: Allyn and Bacon.

Kemmis, S. (1983). Action Research. In T. Husen \& T. Postletwwaite (Eds.), International Encyclopedia of Education: Research and Studies. Oxford: Pergamon.
Djamarah, Syaiful bahri. 1994. Prestasi Belajar Dan Kompetensi Guru. Surabaya: Usaha Nasional.

Sukiman, Pengembangan Media Pembelajaran, (Yogyakarta: Pedagogia, 2012), h. 187188.

Cecep Kustandi dan Bambang Sutjipto, Media Pembelajaran Manual dan Digital Edisi Kedua, (Bogor: Ghalia Indonesia, 2013), h. 64

Howards S. Barrows \& Robyn M. Tamblyn, Problem-Based Learning, an Approach to Medical Education, New York: Springer Publishing Company, 1980, 1. Safaat,Nazruddin h. 2012. "Pemrograman Aplikasi Mobile Smartphone dan Tablet PC berbasis android, Cetakan Pertama, Edisi Revisi, Penerbit Informatika Bandung.Bandung 